SF-239 食物停滞の少ない幽門保存胃切除の腹腔

鏡補助下切除への応用

癌研有明病院消化器外科

布部創也，比企直樹，福永哲，細井則人，名取健，

大山繁和，斎浦明夫，大矢雅敏，瀬戸泰之，山本順司，

山口俊晴

幽門保存胃切除 (PPG) は、幽門輪を温存することで 胃切除後症状を少なくする術式である。一方、食物停滞 による術後早期の胃内容排出遅延が問題となる。われわ れは開腹幽門保存胃切除 (CPPG)において迷走神経、幽 門部の血流を温存した術式を定型化することで停滞の少 ないPPGを施行し、これを腹腔鏡補助下PPG (LAPPG) に応用した。対象は2003年1月から2006年 3 月までに胃癌に对し施行した LAPPG39例、CPPG51例。 2 群間で手術時間、出血量、リンパ節郭清個数、ガス排 出日、鎮痛剂使用回数、術後早期の食物停滞の有無、在 院日数を比較。幽門洞の長さは $3 \mathrm{~cm}$ 、右昌、幽門下動脈、 迷走神経（幽門伎、腹腔技）温存。LPPG vs CAPPG： 手術時間: $236.4 \pm 7.2$ vs $161.2 \pm 5.1(\mathrm{p}<0.001)$ 。 出血量: 65.4 \pm 12.3 vs $160.7 \pm 19.6(p<0.001)$ 、 リンパ節郭清個数: $36.2 \pm 1.8$ vs $29.0 \pm 1.3(\mathrm{p}=$ $0.001)$ 力又排出日 $: 2.3 \pm 0.1$ vs $2.7 \pm 0.2$ ( $\mathrm{p}=0$. $049)$ 、鎮痛剂使用回数: $4.4 \pm 0.7$ vs $5.0 \pm 0.7$ $(\mathrm{p}=0.518)$ 、在院日数 : $11.0 \pm 0.7$ vs $11.7 \pm 0.3$ $(\mathrm{p}=0.308)$ 、食物偟滞 : 3 例 $(7.7 \%)$ vs 3 例 $(5$. $\left.9^{\circ}{ }_{0}\right)$ 。適切な幽門洞の保存長と良好な血流維持を含む手 技し定型化が術後早期の食物停滞を予防した可能性があ る。LAPPG てはCPPG と比較し、出血量、ガ排出日 数は有意に少なく、食物停滞は同程度に少なかった。手 術時間が長いが許容し得るもので、食物停滞の少ない CPPG は L.APPG に応用可能であった。

SF-240

噴門側胃切除後空腸パウチ再建の評価

久留: 大学外 $f$

早地少史朗，今泉拓也，宮城委史，矢野正二郎，

白水和雄

[目的］噴門側胃切除後の空腸パウチ再建法については 議論のあるところであり、とくにその長期成績について ひ栝过は少ない。今回嘪門側胃切除後の空腸パウチ再建 法の合併症、保状態、後遗症、愁訴について食道胃吻 合との比較検討を行った。[対象]1994年から2003年の10 年間に当幵で切除された噴門側谓切除症例60例を対象と した。空腸パウチ再建を A 群、食道胃吻合を B 群とし

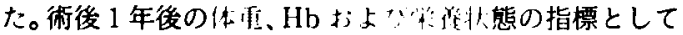
T.P, alb. Che，T.chov方化を比較した。また術後ア ンケートによる患者い, 部について調查した。[結果] A 群11例、B 群49例。年战合は B 群でA 群に比較し有意に高 かった。手術時間、術中出血量はいな゙をし A 群が B 群に 比べ有意に高値でちったが、術後在院日数は有意差は認 めなかった。術前合併症は22例に户ら机うち19例は B 群 であった。術後合併症は23例にみられ、A 群は B 群に比 べ合併症・後遗症は多く、A 群には腸閉塞、食物停滞、 B 群には吻合部狭窄ガみられた。作更変化はA群が有意 に変化が大きく、筷䕊状態の変化に差は認めなかった。 アンケート調査ではA 群は食後もたれ感、腹痛、B 群は 胸やけ、食後もたれ感が上位にみられた。[結語]空腸パ ウチ再建は食道胃吻合と比べ、栄養状態は優九ていると はいえず、腸閉塞、パウチ内の食物停滞が問題と考えら れた。
SF-241 幽門側胃切除後の機能温存再建としての

Pouch 間置術の評価

国立南横浜病院消化器外科 ${ }^{1)}$, ゆりのきクリニック2), 東 邦大学大森病院消化器外科 ${ }^{37}$

池田正視 ${ }^{21}$ ，上田括郎 ${ }^{21}$ ，大橋佳弘 ${ }^{31}$ ，名波竜規 ${ }^{31}$,

竹内俊介 ${ }^{3)}$, 龍雅峰 ${ }^{12}$, 渡辺正志 ${ }^{3)}$, 宮入守 ${ }^{31}$

【目的】われわれは予後を期待できる幽門側胃切除症例 においては機能温存手術として Pouch 間置術(PI)を施 行している。今回はその長期成績に加え、従来の Billroth I 法 (BI) と Roux-en-Y 法(RY)による再建症例と比较 検討したので報告する。【対象】胃癌にて幽門側胃切除術 後 1 年以上経過した61症例(PI28例、BI23例、RY 10例)。 【方法】全群て 1 年後の愁訴 (CS : 各愁訴を 0 ；なし、 $1 ＼mathrm{~ ： 軽 度 、 ~} 2 ＼mathrm{~ ： 中 等 度 、 ~} 3$ ：重度で表記し合計しスコア 化)、術前を $100 \%$ とした体重(BW)、1回食事攝取量 $(\mathrm{FV}) 、 1$ 日食事回数 (MF) の調查および内梘鏡検査を 施行し比較検討した。なお PI 群は術後 7 年まで経時的 に調查し、Pouch の変化を観察した。(成績】PI, BI, RY 群で、術後 1 年目の CS は0.32，0.56、0.25で、BW(\%) は89.4, 91.4, 92.1、FV(\%)は81.3, 70.8, 81.3、 $\mathrm{MF}$ は3.4，3.0，3.1てあった。逆流性食道炎、残胃炎は BI 群に多くみられPI，RY 群は軽度であった。食物残楂は PI 群で少なかった。PI 群は 5 年後に CS は0.0、BW(\%) は87.5、FV(\%)は89.4、MF は3.2であった。結論】幽 門側胃切除後のPI は、BI，RY と術後 1 年では体重、 食事摄取状況に関して有意な差は認めなかったが、食道、 残胃の状況および長期 QOL は良好であり、優れた再建 術式であると考える。

\section{SF-242 幽門保存胃切除術の工夫}

横浜市立大学消化器・腫瘍外科学 ${ }^{11}$, 横浜市立大学附属市 民総合医療センター消化器病センター21

野村直人"，国崎主税 2)，牧野洋知 ${ }^{21}$ ，小野秀高"), 秋山浩利"1, 嶋田紘 ${ }^{13}$

【目的】胃癌に対する幽門保存胃切除術 (PPG) と幽門 側胃切除術 (DG) を比較し，QOL を損なわない $\mathrm{PPG}$ ついて検討した。【対象】PPG 施行 31例と、DG 施行48例。

【方法】周術期、術後自覚症状, 術後 2 年目と術前の体 重比，食事摃取量比，及び，術後内視鏡所見を両術式間 て比較した。また，PPGて，残胃の形㦔と術後QOL と の関係を検討した。【結果】1，手術時間に差はなかった が、出血量は DG 群で有意に多く、術後在院日数はPPG 群で长くみられた。2，体重比は $\mathrm{PPG} ： \mathrm{DG}=94.5 \%$ ： $89.5 \%$ とPP の体重減少が少なかった。食事摄取量比 に差はなかった。3, 残胃粘膜の半分以上の発赤は, PPG : $\mathrm{DG}=27.6 \%: 67.5 \%$ はられた。4,むねやけは

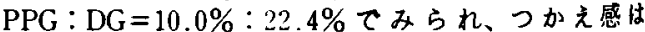
PPG : $\mathrm{DG}=16.1^{\circ} \mathrm{o}: 10.4 \%$ みられた。ダンピンク症 状に差はなかった。 5 , 残胃計測：牫胃長軸は，つかえ 感 $(+):(-)=12.4 \mathrm{~cm}: 14.4 \mathrm{~cm}$ と残胃容糟が小さい とつかえ感を生じる傾向にあった。前庭部残存距噰蚛， 長期入院：短期入院 $=2.4 \mathrm{~cm}: 3.3 \mathrm{~cm}$ と、前庭部残存睲 離が短いと入院期間が長くなる傾向にあった。結語】 PPG は、残胃炎，むねやけが少なく、前庭部残存距崔を 長く、残刿を大きくすることにより、入院期間を短く、 術後のつかえ感が改善でき、QOLを向上させる術式と考 えられた。 
SF-243胃癌で幽門側胃切除術を受けた症例の Quality of life と、空腸パウチ間置再建法の効果 金沢大学がん局所制御学

木南伸一, 尾島英介, 木下淳, 藤田秀人, 二宮致, 伏田幸夫，西村元一，藤村隆，太田哲生

【目的】幽門側胃切除術後の再建法は Billroth I 法(B 1)もしくは Roux-en Y 再建 (RY)が一般的だが、機能 温存術式として空腸パウチ間置再建法 (JPI)が行われて WるJPI では食生活習慣の維持と檠落排泄防止・逆流防 止の機能が温存されるが、Quality of life (QOL)の向上 に奇与するかは不明である。幽切泟例の包括的尺度 QOL 調查し、QOL に影撽する因子の検討と、JPI の QOL 改 羓の橫証を行った。【方法】80瓷末淦・performance status (PS) $0-1$ て無再発の幽切症例を対象に、WHO/QOL 26 謂查票 (金子書房) と術後愁訴調查票からなる郵送〉 ンケートを行った。愁訴調查票は食生活習慣・食事量・ 愁訴・便の性状・face scale $の$ 各項目ことに 4 段階に評 占し集計した。方 face scale 以外の 4 項目にPS・年 齢・徒後経過年数・郭清度、そして再建法を加えた 9 項 目に関し、WHO/QOL26の得点に及里す影䉕を stepwise regression analysis で評価した。【結果】有效回答 は B 1 27例・RY 23例・JPI 77例から得られた。愁訴調 㚗て JPI の食生活習慣はB 1・RYより有意に良好であ ったが、QOL 平均値は B $13.55, \mathrm{RY} 3.45$, JPI 3.51 と術式間で差がなかった。重回㷌分析で選択された説明 変数はPS·愁訴・年㱓であった。【結語】幽切拉例心 QOL は低々ない。幽切例のQOLを大きく左右するのはPS・ 愁訴・年龄て、、再建法の関与は小さかった。JPI は術前の 食生活習愐が維持される優れた術式だか、包括的 QOL を改善するまでの奻果は示さなかった。

\section{SF-244長期経過した早期胃癌における幽門輪温} 存幽門側胃切除術後症例の病態

日本齿科大学外科"，日本大学小児外科 ${ }^{21}$ ，藤崎病院外 科 ${ }^{31}$ ，日本大学救命センター4)

富田凉一", 五十崫誠悟 ${ }^{21}$, 他田太郎 ${ }^{21}$, 越永従道 ${ }^{21}$, 藤崎滋 ${ }^{3}$, 丹正勝久 ${ }^{4}$

【目的】早期胃后術後 5 年目での幽門輪温存幽門側胃切 除術 (A 群) と幽門側胃切除術 (B 群) のQOL を検討し た。【対象】A 群 8 例 (男 6 例、女 2 例、33-70歳、平均 63.5 歳) と B 群22例 (男14、女 8 例、38-68歳、平均 60 . 8歳)であり、健常人15例（C群：男性10例、女性 5 例。 40-68歳、平均60.1歳) を対照とした。方法は直接問診 法、胃排出機能検査 (固形食排出機能は $99 \mathrm{~m}$ Tc 標識全弹 を用いた radioisotope 法、液体食はオレンジジュースを 用いた acetoaminophen 法)、食道胃内視鏡検査、腹部超 音波検査などを用いた。【成績】 $\mathrm{A}$ 群は B 群に比較して、 食欲低下、逆流性食道炎症状、早期ダンピング症状、体 重減少、内視鏡的逆流性食道炎、内視鏡的残胃炎、超音 波による胆䐣胆石症などが有意に少なく良好であった

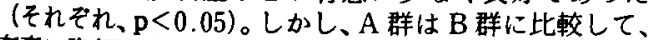
有意に腹部䛗满感を訴えた $(p<0.05)$ 。固形食胃排出機 能は、排出パターンに3群間に差は認めなかったが、A 群は B、C 群より有意に排出遅延を認めた（p<0.05）。 液体食胃排出機能は、B 群は A、C 群より有意に促進し

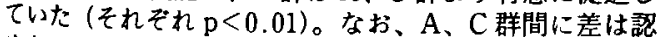
めなかった。【結論】A 群は B 群より術後 QOL は改善し たが、腹部跀满感恃固形食胃排出機能遅延により長期持 続する。
SF-245幽門保存胃切除術後の機能評価の検討

広島大学原医研腫場外科

田透和照, 吉田和弘, 浜井洋一，右近圭，水入寛純，

恵美学, 檜原淳, 山口佳之

[目的]幽門保存胃切除術 $(P P G)$ と幽門側胃切除術 (DG)の各術式における術後愁訴, 栄責状態, 残胃排出能 を比較検討した。［対象と方法]2003年 1 月以降の早期胃 癌症例のうち PPG10例と DGl6例を対象とした。術後愁 訴はアンケート調査を行い体重変化、栄鸢状態の評価を 行った。13C 呼気試験は13C-octanoic acid $100 \mathrm{mg}$ を含 む固形食を摄取後，最大量排出時間(Tlag), $50 \%$ 排出時 間(T 1/2),Gastric empt yingcoefficient を比較し た。超音波法はコンソメスープ飲用後胃排出能、前庭部 運動能，十二指腸胃逆流を測定し健常人(334人) と比較し た。[結果] アンタート結果からは PPG 群では食後の 胸焼けは少ないが、腹満感が継続する傾向があった。食 事摄取量、栄養指標に有意差を認めなかった。呼気試験 ではPPG 群、DG 群で各々T 1/2：2.94：2.12時間、 Tlag：2.63：1.19時間と有意にPPG 群で排出遅延を認 めた。超音波法ではPPGにおける胃排出能は 3 ヶ月以 降では健常人と同等であった。[結語] PPG はダンピン グ症状の防止という点で有用な術式と考えられるが術後 早期に腹部臌满を認めろ症例もあり今後の課題と考えら れた。

SF-246早期胃瘦 EMR 適応拉大病変に対する ESD の妥当性（開腹胃切術と比較検討して）

杏林大学外科

竹内弘久，阿部展次，柳田修，森俊幸，杉山政則， 跡見裕

背景、目的)早期胃癌の治療法としてESDは、リンパ節 転移かないと考えられている適応搪大病変に対しても手 術と同等の治療成續が得られると考えられている。本検 討は，適応拡大病変に ESD が妥当な治療であるか否か を検証. 対象，方法) 2001 年 6 月から2005年 6 月まてに $\mathrm{ESD}$ が施行された早期胃愿109例のうち適応拡大病変32 例 (平均 67 歲：男/女 $=31 / 1$ 例) と同時期に適応拡大病変 に対して開腹胃切が施行きれ122例(平均67紫: 男/女=

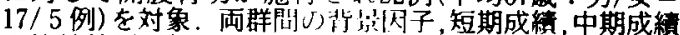
を比較唡討.結果)背景因子：ESD 群は有意に男性が多 かった $(97 \mathrm{vs} 77 \%)$. 田切群で淋分化型が有意に多かった (3 vs27\%)，短期成續：手術時間(平均134vs277分)，偶 発症/合併症発生率(19vs41\%), 術後在院期間(平均 8 vs27日)はESD 群で有意に良好であった。ESD群の偶 発症/合併症的穿孔 $(6 \%)$, 後出血 $(13 \%)$ ，術後肺炎 (3\%). 胃切群では吻合部狭空 $(14 \%)$, 縫合亲全 $(9 \%)$ カテ/創感染 $(9 \%)$, 不整脈合併 $(5 \%)$ ), 敗血症 $(5 \%)$. 輸 血は固切群のみ認めた $(5 \%)$. 術後体重減少は ESD 群 で2\%.胃切群 $9 \%$ であった.国切群で術後在院死亡例を 1 例 $(5 \%)$ )認めた.中期成續：ESD群 1 例に遗残再発を 認めたが、APCの追加治療で癌は消失 ( 2 年経過中)。転 移再発，死亡例は認めす。胃切群 1 例に異時再発を認めた が残角切除で癌は消失(10ヶ月経過中), 結猃, 考察) ESDは開腹昌切に比べ安全で、同等な中期成䋶が得られ た.より長期の検討で同等な成綪が得られれば，適応搪大 病変にESDが標準治療になり得ると考えられた 
SF-247幽門側胃切除術, Roux en Y 法再建にお ける $13 \mathrm{C}$ 呼気試験を用いた消化吸収機能および術後胆竞 運動機能一他の再建術式との比較検討

広島記念病院

中村浩之, 森藤雅彦, 藤本三意夫, 宮本勝也,

横山雄二郎, 清水亘, 武藤矄, 中井志郎

【目的】胃切後再建方法は様々て，消化吸収機能からみ た機能温存の報告は少ない. 幽門側胃切除 Roux en Y 法 (以下 R-Y) の消化吸収機能、胆更機能を比較検討.【方 法】術後 6ヶ月以上経過患者 33例 (R-Y 15例, Billroth I 法 (以下 B-I) 7 例, 分節切除 5 例, 胃全摘 6 例)、健 常者10例を対象。13C 呼気試験は13C 標識混合長銷中性 脂肪を用い，呼気中排泄を 1 時間ごと7時間まて採取。 ピーク値を呈するまでの時間(以下 T max)，7時間累和

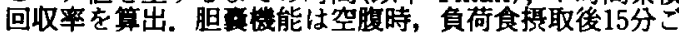
と60分まて Ellipsoid 法で胆收摍率 (以下 GBEF) を模 討.【結果】13C 累糟回収隼は R-Y $5.6 \pm 2.4 \%$, B-I 7 $2 \pm 1.8 \%$, 分節切除 $9.0 \pm 3.2 \%$, 健常者 $15.5 \pm 6.0 \%$ と胃 切後は健常者より劣るものの分節切除が最も良好であつ

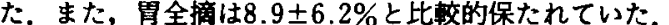
我々が消化吸取棱能 $の$ cut off 值としている5.0\%以下 の症例は分節切除症例には認めなかった. T max は R-Y 405士30分と，R-Yが有意に高值であった $(p<0.05)$ ． た宸水化物消化吸収機能低下を示唆する空腹時呼気中水 素濃度 $20 \mathrm{ppm}$ 以上の症列仔認めなかった。 GBEF は R一 Y $44.0 \pm 10.9 \%, B-I 45.1 \pm 9.5 \%$, 分節切除 $50.0 \pm 11$. $2 \%$, 健常者 $66.3 \pm 16.0 \%$, 分節切除が最も良好であっ た.【結論】 R-Y の脂肪消化吸収機能は B-I, 分節切除な ど十二指腸を経由する術式と比較してやや劣るものの， cut off 值以下の症例は少なかった。また胆機能との関 連性は今後の課題である。

SF-248 迷走神経温存幽門保存胃切除術の評 価 一幽門側胃切除術との比較検討一

吱皋市民病院外科

山田誠，種村展巳，大下裕夫，日下部光彦，波頭経明， 足立尊仁, 松尾第, 水井慎一郎, 青木幹根, 浅野智成

【目的】迷走神経温存幽門保存胃切除術 (PPG)の成綪を 幽門側胃切除術(DG) と絰合的に比較検討した。【対象と 方法】2001年12月から当科て施行したPPG40例の中て術 後 6 ケ月以上経過し、経過得察の胃内視鏡を施行された 29例を对象とし、同時期に施行された深迋度 MP まての Billroth I 法再建を行ったDG21例と比较した。【成繶】

1 ) PPG 群で 1 例に術後早期の胃排泄障客を認めたが、 DG 群ではみられなかった。また、術後入院日数は PPG 群: $19.1 \pm 5.1$ 日 DG 群: $21.3 \pm 5.4$ 日と差を認めなか った。2)術後の体重変助は DG 群は術後半年と 2 年目も 共に術前 $990 \%$ 、PPG 群は術後半年で $91 \%$ 、2 年目て 92\%と両群間に差を認めなかった。3)術後のへモグロビ ン・総蛋白値の変動は PPG 群とDG 群との間に差はみ られなかった。4)DG 群ではダンピング症状が4.8\%に、 下廊が38.1\%にみられたのに对しPPG 群ではみうな かった。 5)内視鏡所見ては PPG 群て 1 例を除いて残存 幽門洞の蟭動が保たれていた。PPG 群はDG 群に比べ食 物残渣が多く、食道炎が少ない傾向です、牫胃炎は有 意に少なかった。6 邲清リンパ節個数はPPG 群: 28 , $9 \pm 12.2$ 個、DG 群: $28.8 \pm 11$.1個と荎を証めなかった。 また、現在のところ両群共に再発を諰めていない。【ま めIPPGは、DGと比較し根治性に差はなく、QOLの点

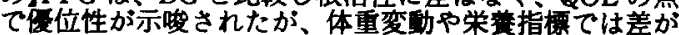
ないため、さらなる症例の菓䅡と長期の経過䤄察による 評価が必要と考えられた。

\section{SF-249} 早期胃癌に対する幽門輪温存胃切除術の 栄秦評価

東京女子医科大学東医療センター

勝部隆男, 今野宗一, 村山実, 谷川敦子, 清口佳奈子, 久原浩太朗，佐川まさの，吉松和彦，塩澤俊一, 島川武， 成高義彦, 小川健治

（はじめに）幽門輪温存胃切除術 (PPG) は早期胃息に 対する機能温存手術の1つである.われわれは呼気試駼 を用いた胃排出能の検討から, PPG ては従来の幽門㑡周 切除 (DG) にみられる排出元進がないことを報告してき た.しかし，術後の夈䬥状態に関する幽門陯温存の有用 性はいまだ明らかにされていない。そこで，幽門輪温存 の有無別に術後の嗪養状態を検討してみた。（対象上方 法） 40-60歳代の早期胃癌39例（PPG 15例，DG 24例) を対象に, 術前 BMI 值(高値群：25以上, 標準群：25末 満) 別に術後 1 年, $2 \sim 3$ 年経過時の栄養状热を評洒し た。栄蓄状態の指標は体重比（術前を100とした比率）， 血清 TP, Hb, Fe, Vitamin B12值, 骨密度 (腰椎側面) を用いた。 (結果) PPG における体重比は, 高値群(郝前 $65.4 \mathrm{~kg}$ ) で術後 1 年 $92.5 \%$, 術後 $2 \sim 3$ 年 $94.8 \%$, 標隼 群 (術前 $58.8 \mathrm{~kg}$ ) で各 $92.8 \% ， 92.8 \%$, DG で，高值 群 $(79.2 \mathrm{~kg})$ で各 $90.8 \%, 95.6 \%$, 標準群 $(56.0 \mathrm{~kg})$ て 各93.5\%，89.9\%であった。体重の回復は高値群で良好 であったが，術式による差はなかった。術後の血清値や 骨密度と術式, 術前 BMI 值との関連はみられなかった。

(結語) PPG 後の栄養状態は術前 BMI 值に影䈉されて おり, 幽門鍽温存の有用性は確認できなかった。

\section{SF-250 胃癌における幽門温存術式の評価}

国立病院機構四国がんセンター

栗田雚, 野崎功雄, 久保義郎, 棚田稔, 大田耕司, 高䳋成光

胃窎の機能温存術式のうちで幽門を温存する術式に関し 検討した。【対象と方法】対象は，2002年から現在まてた 当施設において行われ， 1 年以上のフォローアップがる されカルテ記载の明らかな噴門側胃切除（空腸間置再 建：26例）と幽門保存胃切除21例. 術後約 1 年の時点㹸 おける，つかえ感，嘌吐，逆流性食道炎（逆食）の各应 状, Dumping 症状, 体重の変動, 内視鏡上逆食所見, 快 窄，食物残椬の有無を検討した。【結果および考察】嗔門 側胃切除，幽門保存胃切除の順に，つかえ感（あり/な L) $: 5 / 21,21 / 0$, 喧吐：1/25,21/0，逆食症状：0/ 26,21/0, Dumping 症状(あり/なし)；1/25,2/18, 体重減少率 $( \pm 0 /-10 /-20 /-30 \% /$ 不明 $) ; 2 / 10 / 9 / 3 /$ $2,1 / 11 / 8 / 0 / 1$ ，内視鏡上逆食所見（あり/ない）； $0 / 26,0 / 21$, 狭窄 (あり/なし) $; 2 / 24,0 / 21$, 食物 残楂 (あり/なし)；3/23，5/16であった。噴門側胃切 除時の食道残胃吻合との比較では，空腸間置術に有利な 点が多く、幽門側胃切除時の Billroth I 法再建との比校 では，幽門保存術式が有利な結果であった。【まとめ断 門を温存する 2 術式は，適応に制限があるものの，囎切 時の再建法において conventional な食道残胃吻合から 空腸間置とする限りにおいて有利な術式と考えられた。 


\section{SF-251早期胃癌手術例における幽門側胃切除術} および幽門保存胃切除術の比較

福島県立医科大学第一外科

在瀨善一郎, 寺島雅典, 大谷聡, 西形里絵, 添田暢俊, 㩐村省吾, 大須賀文彦, 星野豊, 木暮道彦, 後藤满一

目的：早期胃癌に対する幽門保存胃切除術は低侵葲、機 能温存を目指した術式であるが、現在まで明らかな有用 性の確証は得られていない。今回我々は早期胃癌に対し て手術が施行された幽門側胃切除術症例、幽門保存胃切 除術症例において術後の栄養学的指標を比較検討した。 対象と方法：H14年より H17年に早期胃病に対し切除

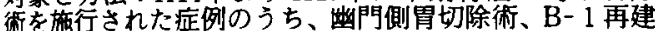
例(DG 群) 19例およU゙幽門保存胃切除術例(PPG 群) 11 例を対象とした。耐群における手術時間、出血量、術後 在院日数、術後 2 年まての体重、血清絰蛋白 (TP)、血色 素(Hb)を比较検討した。結果：PPG 群、DG 群における 手術時間 $(191+31$ 分 vs $184+44$ 分 $)$ 出血量 $(230+120$ gs $194+110 \mathrm{~g})$ 術後在院日数 $(13.0+1.3$ 日 $12.3+$ 1.5日）には差を認めなかった。術後合併症としてはDG 群て㓣感染を1例、PPG 群て細菌性腸炎を2 例認めた がその他の合併症は認めなかった。両群とも第 1 病日 に全例胃管抜去が可能であった。体重、Hb の推移は両群 間で差を㒛めなかったが TPはPPG 群で良好に推移 し、術後 6 ケ月で有意な差を認めた。術後愁訴に関して は、DG群で逆流性食道炎を2例、ダンピング症候群を1 例に、PPG 群で食後腹部㬨满感を 1 例に認めた。結語： PPG 群はDG 群に比し術後TP の推移が良好であり、夕 ンピンク症状や逆流症状も少ない事から早期癌に対して 有用な術式と考えられた。

SF-252 QOL を考慮した幽門側胃切除術後再建 -2 重空腸基ダブルトラクト法

大分大学消化管外科"，大分大学第 2 外科 ${ }^{2)}$

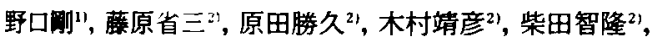

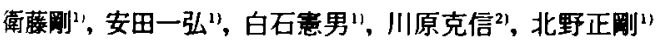

【目的】幽門側胃要全摘術後の再建は、逆流性食道炎、 逆流性残胃炎、小胃症状、ダンピング症状などを防止て きることが望ましい。教室では残胃・十二指腸間 2 重空 腸晎ダブルトラクト法を考案、施行しているので術式を 紹介し成績を報告する。【成續】本再建法を65例に施行し た (男性39例、女性26例)。術後自党程状として 3 例 (4. 6\%)に軽度の腹部橵满感を認めるのみて、その他の自賞 症状（逆流症状、小胃症状、ダンピング症状）を認めな かった。さらに、同時期に施行した他の再建術式(122例) と比较して次の項目で有意に良好な結果を得た。( 1 体 重の変動：平均値で術前の $96 \%$ まで復した、（2）食事搷 取量：術前と有意差なし、(3)ハリリウム造影、内視鏡検 亘による逆流の程度：逆流なし、（4）24時間食道内 $\mathrm{pH}$ 测定、(5) ガストロシンチグラフィーによる排出試験、

（6）患者の満足度謂查 (問猃票)。【結論】幽門側团重 全摘後のQOLを考虑した本術式は極めて有用な術式と 考える。

\author{
SF-253 噴門側胃切除・空腸間置術の評価 \\ 都立駒込病院外科 \\ 荒井邦佳, 岩崎善毅, 高橋慶一，山口達郎，松本寛， \\ 安留道也
}

噴切は施設間での相違が多く、評価を含めて未だコンセ ンサスの得られていない術式である。当院では上部の早 期胃瘐に対する縮小手術として用いており、QOLの向上 のために数多くの改良を加光現在に至っている。当院で の術式の特街は、1）2分の1胃切除、2) D 1+No.7 郭清て肝枝、腹腔枝、幽門枝は温存、3) 間置空腸は10 $\mathrm{cm}$ でパウチなし、4)幽門形成なし、5）完成時の形態 を重視し新たな胃角を作成する、などである。今回は、 我々が行っている噴切について改良の根㧐と今後の問題 点を明らかにしたい。1. 胃切除とリンパ節郭清：U、UM の癌におけるNo. 4 d $5 ， 6$ リンパ節転移は深達度 SSから無現する。安全性を考え SM までの早期胃癌が 適応となり 2 分の 1 切除としている。2，神経温存の意 義：これまての検討では温存の有無と胃切後胆石症の発 生には相関が得られなかった。テーピングと牽引による 術中操作で神経麻瘦が起きた可能性があり現在は神経を 童引しないで温存している。3.間置空腸：食事摄取によ り自然にパウチ様に拡張することからパウ手作成は不要 と考える。4. 完成時の形態：間置空腸の直線化が逆流を 防止し、つかえ感を軽減する。二方、1994年から2003年 までの66例におけるQOLの検討て、全摘と比較した最 大のメリットは筫血 (鉄欠乏性、VB12欠乏性) の発生が 少ない傾向であった $(\mathrm{p}<0.13)$ 。全摘とQOL を比較した 場合、絶対的な優位はないが、患者満足度が高い術式と いえる。

\section{SF-254}

高度進行直腸癌に対する術前化学療法の

試み

京都大学外科

長山聡, 長谷川傑, 川村純一郎, 野村明成, 岡部寛,

伊丹淳，渡辺剛，佐藤誠二，䳋田裕，坂井義治

広観曲の側方リンパ節転移を来たした場合や周囲喏器へ 直接漫潤している場合などの高度進行直腸壆の治潦に際 してこれまで根治性を追及して骨盤内䏯神経および内 腸骨血管合併切除を伴う側方部清、あるいは贯盤内满全 摘や仙骨合併切除など侵鮁の大きな手術を余儀なくされ ることが多いが、その反面、術後のQOL 低下が著しい。 一方て、結腸直腸癌に対する化学療法としてFOLFOX] FOLFIRIが省入されるとともに、化学療法の治療成續 は格段に改善してきている。当科はこれまでに74症例の 結腸直腸癌の治療に FOLFOX/FOLFIRI (FOLFOX 57 例、FOLFIRI 17例)を行っている。その内訳は再発·転 移庭例69症例、アジュバント治療 5 例であり、現時点て は概な良好な治療奻果を得ている。これまての治療経験 をもとに当科では高度進行直腸癌の術前化学療法として FOLFOX/FOLFIRI を行うことを検討している。腫痬縮 小奻果の期待できる化学療法を術䏍に施行し腫啅の down-staging を図ることて、根治性を保ちつつ手術の 侵整を軽搌できる可能性を追求したいと考えている。今 回、術前化学療法が著効した症例も提示するが、症冽数 が少なく術前化学療法の治療成績に関して結論うけるこ とは難しい。しかしながら手術困難症例が術前化学療法 にて手術に持ち込める場合があることも事実である。今 後はさらに症例を增やして検討を重ねていく予定であ る。 
SF-255

大腸癌肝転移・肺転移に対する外科療法

のベストチョイス

広島大学大学院先進医療開発科学講座外科学 ${ }^{11}$, 広島大 学大学院内視鏡外科学講座 ${ }^{21}$

住谷大輔 ${ }^{1}$, 池田聡 ${ }^{21}$, 小島康知 ${ }^{21}$, 吉满政義 ${ }^{21}$, 小川尚之 ${ }^{11}$, 倉吉学",, 吉田誐", 高合有二", 新井春華 ${ }^{1}$, 川掘勝史", 宮田義浩"，板本敏行"1, 岡島正純 ${ }^{21}$, 浅原利正 ${ }^{11}$

[はじぬに]大腸痹肝転移・肺転移に対する治療法とし て外科的切除を第一に考慮することに異論は少ないと思 わ机る。我々は大晹盘肝転移、肺転移は皘極的な外科的 切除を基本方針乞してきた。[大腸痛肝転移] 同時性・異 時性に関らす完全切除可能な症例は $\mathrm{H} 3 \tau$ 七切除を考 盧する。術後は予防的 5-FU 肝動注療法を行ってきた。 当院での大腸癌肝転移治愈切除例 (CurB) て、動注群 5 年残訮無再発率 $81.4 \%$ ，5年生存率 $63.1 \%$ 、非動注群は そ机飞机 5 年残肝無再発率 $42.3 \% 、 5$ 年生存率 $41.2 \%$ て あった。残肝再発死亡は動注群 $30 \%$ 、非動注群 $89.5 \%$ て あった。[大腸澓肺転移]手術適応は完全切除可能なもの としている。切除は原則として胸腔鏡下手術(VATS、

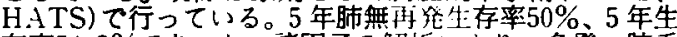
存率 $54.2 \%$ であった。諸因子 $\sigma$ 解析により、多発、肺手 術時60歳未满、部分切除、両側轻移、原発結腸癌症例て 予後不良傾向にあった。[問題点と今後し展望]大腸癌肝 転移に対する治療として、肝切除とその後の肝動注は予 後の改善及ひ残訮再発の抑制には効果的であったが、他 部位への転移、再発の問題か残り、全身化学㞠法この組 み合わせが考虑されるへきである。肺転移の切除成績は 比㜞的良好ごあるが予後因子によるさらに袘密な手術適 応基準の検討が必要であろう。

\section{SF-256} 進行再発大腸癌に対する化学療法の方向

性: escalation or de-escalation?

三重大学消化管 - 小児外科

井上靖浩，渡部秀樹，廣純一郎，尾䳋英紀，問山裕二， 小林美奈子，三木蔀雄，楠正人

大腸盘における化学滰法は各種 active drug の登場で、 著しい進步をとげており、その treatment option も非常 に豊富になってきた。しかしそれら key drugをどの夕 イミングでどう使い分けるか、また荣学的治療における 化学療法の位置付けち十分明らかにはされていない。そ てて大腸癌化学撩法の best choiceについて、当科ての IXIC (Pharmacokinetic Modulating Chemotherapy) を中心とした集学的治療から検討した。治療的化学療法 を施行した進行・再発大腸疸127例を対象とし、SD、PR 症例に施行した secondary surgery、放射線、RFA など の集学的アプローチの有無と治療成綪を検討した。平均 観察期間19.0ケ月で全体の MSTは24.7ヶ月であった。 集学的アプローチが併用された52例の累稹 5 年生存染は $51.1 \%$ で、化学㞠法単独群(MST16.0 月月)と比べ有意に 予後良好であり、この傾向は肝、肺転移、原発切除不能、 腹膜播種、局所再発全てにみられた。また集学的アプロ 一千の57.7\%がCurC であったが、化学療法単独くCur C <Cur B の順に予後良好であった。すなわち患者状況 にあわせて勧学的アナ゚ローチ茅入を目的とした強力な initial chemotherapy 行う de - escalation strategy が、進行・再発大腸癌における一つの治療コンセプトに なりうると考えられた。

\section{SF-257 大腸癌肺転移症例の検討}

東北大学生体調節外科

小林照忠，清井蜸幸，平賀雅樹，木内諴，村田幸生， 大沼忍，佐々木宏之，高見一弘，金子直征，唐澤秀明， 佐々木籍

【目的と対象】教室の大腸癌881例（結腸436例、直腸445 例) のうち、肺転移例について検討した。【結果】結陽て は同時性 8 例 $(1.8 \%)$ 、異時性 4 例 $(0.9 \%)$ 、直腸て仕 同時性 6 例 $(1.3 \%)$ 、異時性 24 例 $(5.4 \%)$ 。〈同時性〉男 女比 $6: 8$ 、平均69.4歳。右側結腸 7 例、左側結腸 1 例、 直腸・肛門管 6 例。原発巣切除率は $85.7 \%$ 、肺切除は 4 例に施行。術後の生存期間は、原発巣切除例89-2197(中 央值590) 日、治痹切除例（原発巣十転移巣）466、754、 1115 日て、 5 年以上生存例は、原発巣切除後に化学療法 を施行した 1例のみであった。〈異時性〉男女比17:11、 初回手術時平均 62.3 歳。大腸癌切除から肺転移までは 180-2191 (中央値881) 日て、占居部位は C I 例、S 3 例、直腸23例。治療は肺切除 8 例、化学 or/and 放射線療 法17例、無治療 2 例 (不明 1 例) て、2 2 年生存率は肺切 除 $83.3 \%$ 、化学 or/and 放射線療法 $35.6 \%$ 、無治療例 0 \%。〈肺切除〉12例に肺切除が行なわれ、転移個数は単発 7 例、2 個 3 例、6 個と 8 個が各 1 例。肺切除後の再発 部位は、肺 3 例、肝 2 例、綐隔と気管が各 1 例で、6 例 は無再発。【考察】結腸癌に比べて直腸澢では肺転移が多 く、異時性が多いことから、術後の followにおいて肺転 移に注意する必要がある。

SF-258 Stage 4 進行大腸癌に対する生存期間 延長を可能とした化学療法と治療戦略 札㹸月寒病院

山田能之, 山光進, 木村弘通

進行大腸癌の治療は近年イリノテカン、オキサリプラチ ンの併用により生存期間の延長が見られたが、median survival time(MST) で20ヶ月の壁を突き崩せないでい る。その原因は有効な化学療法の長期間継続が困難なこ とによる。化学療法中止の原因は有害事象にあるため、 有害事象の少ない、奏効率の高い、繰り返しの出来る reg imenが望まれる。我われは 5 FU(TS-1),CDDP、 Taxan,CPT-11を用いた intermittent FP-weekly Taxan 療法 Intermittent FP 療法、weekly CPT-11磨 法を交代で行い進行大腸癌治療に良好な成績を得ている ので報告する。Stage 4 大腸癌13例の治療結果はCR 2 例、PR 5 例、NC 5 例、PD 1 例で奏効率は $53.8 \%$ てお つた。生存率は1生率69.2\%、2 生率 $61.5 \%$ 、3生率42. $2 \% 、 5$ 生率14.1\%で、MSTは36ヶ月であった。有害事 象は grade 3 とが 5 例と 0 例で、grade 3 以上 $38.5 \%$ てあったが、その内容を見ると血小板减少は grade 2 以 下て、grade 3 は白血球減少とへモグロビン减少のため 対処に困難は無かった。以上の詳紐について報告する。 


\section{SF-259肉眼的他臟器浸潤大腸癌の検討 岐皁大学高度先進外科 \\ 松尾浩，山田卓也，関野考史，木山茂，木村真樹， 井原須, 竹村博文}

【緒言】大腸癌は局所進展の際に炎症性疬着をきたす場 合が多く, 組織学的癌浸潤の有無, 浸潤荿器合併切除の 是非を術中に判断する必要がある。【目的】肉眼的他臓器 浸潤大腸癌の肉眼的・組織学的浸潤の一致率を検討し、 肉眼的他藏器浸潤大腸癌の予後因子を明らかにする。【方 法】1989年〜2005年に当科で施行した大腸癌手術症例 340 例中, 術者が周囲臟器漫潤ありと判断した大腸癌25例を 対象として、肉眼的・組織学的他臟器浸潤の一致率を検 討し、肉腿的他臟器浸潤大腸癌の予後因子を, 比例八ザ 一ド回㫦分析を用いて解析した。解析因子は、組織学的 浸潤 $(+)$, 低分化腺癌, 脈管侵 $(+), \mathrm{n}(+), \mathrm{ew}(+)$, stage IV, 合併切除施行， 3 群リンハ節廏清 $(+)$, 根治 度 C, 術後化学療法 $(+)$ とした。【結果】浸潤の一致率は 全体 $52 \%$ ，結腸癌 $46 \%$ ，直腸癌 $40 \%$ であった。浸潤䑏 器が胃・腸の場合は $75^{\circ}$ 。 , 膀胱の場合は $17 \circ$ 。であった。 対象群全体の 5 年生存率は $36^{\circ}$ 。, 生存期間中央值 (MST) は12力月であった。ew(+)の場合 MST 8 力月, $\mathrm{p}=0$. 004 , 根治度 CO場合 MST 8.5力月, $\mathrm{p}=0.01$, stage IV の場合 MST 8.5 力月， $\mathrm{p}=0.008$ と有為に生存期間が短 かった。【結語】浸潤臟器が胃・腸の場合, 肉眼的・組織 学的漫潤の一致率が高く，合併切除を施行した方が良い。 肉眼的に他藏器浸洞を認めた大腸癌において, ew(十), 根治度 C , stage IV の場合予後不良であった。

\section{SF-260}

政小リンパ節転移からみた大腸癌に対す 万治虔戦路

大分大学消化器外科

安田一弘, 猪股雅史, 田中栄一, 衛藤剛, 末松俊洋、

野口剖, 白石憲男, 北野正㓮

【目的】大腸癌の微小リンパ節転移を調心，至適治療を 明らかにする。【方法】対象は外科切除した SM 癌86例と 術後 5 年以上経過した組的学的リンパ節転移陰性進行癌 (stage II) 56例. SM 癖はリンパ節転移危険因子を調へ, 進行要は予後因子について検討した。検索リンパ節個数 は1934個で, 微小転移は CAM5.2を用いた免疫組織化学 で検出した (厚さ $6 \mu \mathrm{m}$ を 5 切片).【結果】 SM 癌( 1 ) 撤小リンパ節転移率は13\%で，HEでの転移を含めた総

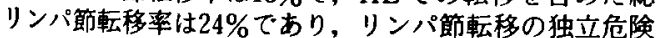
因子は脈管侵熟と簇出であった。リンパ節転移率は SM 浸潤 $1000 \mu \mathrm{m}$ までは 0\%で, 1000-2000 $\mu \mathrm{m}$ は21\%, 2000 $\mu \mathrm{m}$ 以深は $37 \%$ \%ちつた。(2)脈管侵襲と筷出が陰性で あ九ば SM 漫潤 $3000 \mu \mathrm{m}$ まではリンパ節転移を認めなか つた。進行瘦（1）微小リンパ節転移率は73\%で，再発は 27\%であった.（2）臨床病理学的因子も含めて予後と関 連のあったのは微小リンパ節転移 4 個以上と 2 群以上て あり，5年生存率は微小転移 3 個以下力: $83 \%$ \% 4 個以上 が50\%で，微小転移 1 群までが92\%，2群以上が $66 \%$ て あった。【結論】大陽 SM 癌は脈管侵襲と簇出が陰性であ れぱ SM 浸潤が $3000 \mu \mathrm{m}$ まではEMRで根治可能であ り, 進行瘦は組織学的リンパ節転移陰性でも微小転移 4 個以上・2 群以上のもの法追加化学療法功必要であると 考えられた。

\section{SF-261 大腸癌治療ガイドラインの認識度調査 \\ 国立病院機構大阪医療センター外科}

池永雅一, 三嶋秀行, 安井昌義, 宮崎道彦, 石飛真人, 増田慎三, 柏崎正樹, 平尾素宏, 藤谷和正, 高見康二, 中森正二，沢村敏郎，辻仲利政

【背景】2005年 7 月に大腸癌治療ガイドラインが発行さ れ、日常診療でどの治療が最適な治療方針かを決定する のに重要な役割を果たすようになった。【目的と方法】消 化器外科医の大腸癌治療ガイドラインに対する認識度を 調査する目的で、当院のスタッフとレジデント（研修医 は除く)を対象に消化器外科医 19 名と消化器内科医12 名に25問の試験形式のアンケートを行った。その後各 Dr にガイドラインを直接手渡し一読を依頼し、後日再度同 様の25問の試験形式のアンケートを行った。【結果】消化 器外科医は、内視鏡と化学療法の項目で認識度が不良(正 解染が 600 。以下) であった。一読後、内視鏡の理解度は 深まったが、化学療法は不良のまま(正解率が50\%以下) であった。消化器内科医は、内視鏡、StageIV 大腸癌、 化学療法、サーべイランスの項目で認識度が不良 (正解 率60\%以下)であった。【結語】最適な治療方針決定には、 基準となるガイドラインを認識している必要がある。試 験形式をとることにより、当院の消化器外科医と消化器 内科医全員が大腸癌治療ガイドラインを一読した。消化 器外科医も消化器内科医も化学療法に対する認識度は低 く、検討会を行っても治療方針が化学療法以外に傾く危 険性が示唆された。中立の立場で治療方針を決定し医療 の均てん化を実現するには、化学療法に対する記識のレ ベルアップが必須である。

\section{SF-262 \\ 高龄者の下部直腸癌治療におけ肛門機能} 温存手術について

小栖掖昘会病院外科" 学部第 1 外科 ${ }^{31}$

佐々木一晃 ${ }^{11}$, 澤田健 ${ }^{11}$, 江副英理 ${ }^{11}$, 奥谷浩一-1), 高坂一21, 鶴間哲弘 ${ }^{33}$ ，古畑智久 ${ }^{31}$ ，平田公一 ${ }^{31}$

【目的】高咸者の下部直腸癌手術では人工肛門造設術施 行の適応を抬大している可能性がある。今回、高战者の 肛門機能温存手術について検討した。【対象と方法】1999 年から6 年間の肛門管に及ばない下部直腸癌症例を対象 とした。70歳以上の35例 (高龄群) と69歳以下の56例(若 年群) と比較。腸管㕫台可能症例は原則として肛門機能 温存手術施行。本術式在避け万基準は、1)括約筋不全、 2)重箩な併存症、3)卧床状態、03項目。【結果】高

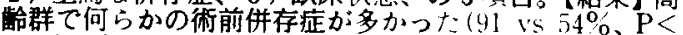
$0.01 ＼mathrm{~ 。 先 に 示 し た 肛 門 括 約 筋 不 全 、 卧 状 状 態 、 そ の 他 重 ~}$ 笛な併存症も高龄群で多い (29 vs $\left.70 、 \mathrm{P}^{\prime}<0.05\right)$ 。高 齢群におけるCur A 手術は $83 \% 、 B ： 6 \% 、 C ： 9 \%$ 、非 切除 $3 \%$ てあった。若年群では各々 $91 、 0 、 9 、 0 \%$ て 両群間に差なし。Cur Aにおけるリンパ節郭清をD 2 以 上でみると高龄群で72\%、若年群で $81 \%$ であった。同様 に括約筋温存手術は高㢼群て7 $76 \%$ 、若年群で $84 \%$ であつ た。腹会陰式直腸切断術となった症例は、全て大きな嗹 疡 $(6 \mathrm{~cm}$ 以上)で深達度 A 2、Ai症例であった。 Hartmann 手術は各群 l例つつて、いすれも基準を満たして いた。肛門機能温存術後の縫合不全は両者とも約 $20 \%$ みられたが、全例軽微でり保存的に軽快した。排便回 数など日常生活て問題なかった。【まとめ)肛門機能を温

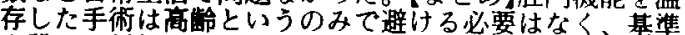
を設けて対処するなら十分に急考のQOLを満たす手術 であった。 


\author{
SF-263 直腸癌前方切除における J 型結腸至再建 \\ の適応と長期排便機能 \\ 近幾大学外科
}

肥田仁一，吉藤竹仁，松本昌子，服部高史，上田和毅， 石丸英三郎, 所忠男, 安富正幸, 塩崎均, 奥野清隆

目的/方法：従来のストレート再建 (S)による前方切除 ては吻合が低位になるほど貯留能が隇少し機能は不良と なる.そして欧米 Guideline には J 型結腸再建 $(\mathrm{J})$ で機 能改善するへしとあり，その evidence は A〜EのBと 強い.すなわち術後 1 年まで J の機能か Sに勝ること は randomized studyで証明されたが、Jの適応(肚門緑 から吻合部までの距崔の上限)とJによる2 年以上の构 能改善の有無が問題.1,3.5 年にJ(48例) と $\mathrm{S}(80$ 例) の 機能を17項の問診からなる点数域 0 (良) 26(不良)のス コアと貯留能(内坧测定)で評価.結果：スコア：[1年] 吻合部まての距敨加 $1-4 \mathrm{~cm}$ ては J5.6. $510.2(\mathrm{P}=0$. 0002)で17項中差があったのは (a) 日中と (b) 夜間の排便 回数,(c)我慢,(d) soiling,パッド、失禁、自己評価 7 項.吻合が $5-8 \mathrm{~cm}$ では J3.5,S5.2(P=0.0038)で差が あったのは(b)、(c), (d) の3 項、吻合が 9-12 cm のS は $3.4 て 5-8 \mathrm{~cm}$ の $\mathrm{J}$ と差かない $(\mathrm{P}=0.9404)$. [3 年] 吻 合が $1-4 \mathrm{~cm}$ て J5.3.S9.6, $5-8 \mathrm{~cm}$ て J3.1.S3.8て 差があったのはそれぞれ 1 年と同じ 7,3 項. [5 年] 吻 合が $1-4 \mathrm{~cm}$ ではJ3.7.S7.3で差があったのは(a), (b). (c).(d)の 4 項.5-8 cm では J2.1.S2.7で差があつ たのは(b), (c) の 2 項. 貯留能: 1 (吻合か 9-12 cm の

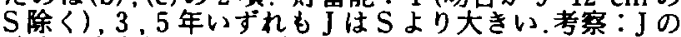
適応は吻合部までの距離が $8 \mathrm{~cm}$ 以下，特に $4 \mathrm{~cm}$ 以下 の超低位吻合に丁は必須.5年でもJの機能はSより良 好. 全直腸間膜切除による局所再発の減少,超低位前方切 除や経肘門吻合の普及、さらにISRの試みによりJのニ ースはより高まる

\section{SF-264} 直腸庫超低位前方切徐術後排便障害：肛

門排便とストーマの比較

杏林大学消化器・一般外科

松岡弘芳, 正木忠彦, 传藤和典, 杉山政則, 跡見裕

【目的】術後排便障害時肛門排便とストーマとの儌劣を 患者主睍により明らかにする。【対象・方法】下部直腸瘦 超低位前方切徐術 (一時的ストーマ造設) 施行し 6 力月 後にストーマ閉鎖を行い術後の経過锶察を施行された 25 例を対象とした。手術前・手術後に排便習愐に成して患 者質問票を行い、排便障害の客稫的指標として直腸肛門 内王娭查を施行した。計測は、water perfusion 型力テ ーテルを station pull through 法にて行った。鈝測定卜 ランスジューサーはスターメディカル社製アンドルファ 一を使用した。【結果】ストーマ閉銷術後 6 ケ月の排便機 能評価では、一日排便回数は平均 $5(2 \sim 15)$ 回、便失禁 スコアは平均 8 と術前に比して有意に増悪し、全例にお いて術後排便障害を呈していた。直腸肛門内压検查ても 肛門括的筋内压は有意な変化は記めないものの、術後の 最大耐用量・直腸容量が有意に減少していた。同時期に 施行したストーマに関する質問票では、25例全例におい て肛門から排便を行う方がストーマケアを施行していた 時期よりむ良いと答えた。その主な理由としてストーマ に関する不安(便が漏れるのでは・パックがはずれる)が 最も多く(25例中15例)、これに続いて具いが気になる(25 例中10例)などあった。【結語】患者主涀上、排便障害時 であっても肛門からの排便は人工肛門に侵っていると考 えられた。
SF-265 直腸腫瘦に対する経肛門的内視鏡下マ1 クロサージェリー(TEM)

相模台病院外科 ${ }^{1)}$, 北里大学医学部外科 ${ }^{23}$

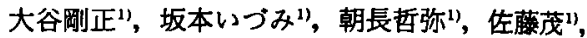
佐藤武郎 ${ }^{2)}$ ，小澤平太 ${ }^{2)}$ ，旗手和彦 ${ }^{2)}$ ，小野里航 ${ }^{2)}$, 中村隆俊2)，國場幸均2)，井原厚2)，渡邉昌彦2)

TEM の自験臨床的検討と今後の問題点につき検討した 【対象】105例に対し TEM 施行。平均年龄63.9土11.3才 であった。【臨床的検討】肛門縁から腫場下縁迄の距麟仗 $9.8 \pm 3.8 \mathrm{~cm}$, 腫湟径は平均 $27.9 \pm 19.6 \mathrm{~mm}$ 、腫偒謤周度 は0.33士0.15であった。手術時間平均 $79.7 \pm 45.7$ 分て、

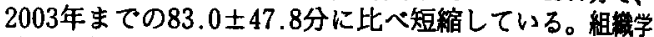
的に74例は高分化腺癌で $(\mathrm{m}: 54$ 例, sm: 19例、a $1: 1$ 例)，その他腺腫 8 例，カルチノイド16例，中分化腺蜔 2 例、肉芽腫 4 例、アミロイドーシス 1 例であった。術後経 口摂取は原則的に翌日から行い平均 $1.2 \pm 0.7$ 日,退院迄 の期間は $5.7 \pm 1.8$ 日であった。【利点】1，肛門緑から梁 い部位の腫瘍も切除可能 2 㹡大視効果で完全切除可能， 3，切除層が確認てき、直腸後壁では全層切除可能 4 ，+ 分な病理組穖検査が可能 5 , 綎合可能で術後合併症が少 ない6、手術侵熟度が覀めて低い【問題点】1,手術䢔底 になる腫瘦占拋部位と大きさ、特に厘瘍高の制限がある。 2 , 手術視野制限がある。3，穿孔や出血の危険性 4 ，手 技が煩雑で訓練、熟練が必要 5 ，高価な手術器具 6 、診 療保険点数の問題【まとめ】TEM は内視鏡的治療特に ESD との適応の重なりが問題であるが、適切な適応のも と熟練した医師が施行することにより安全かつ碓実な手 術手技であると考えられる。

SF-266 直腸癌患者の人工肘門回避のベストチョ イスはどのように意思決定されるか？

関西医科大学外科

吉岡和彦, 岩本慈能, 畑嘉高, 中根恭司, 上山泰男

【背景】直腸癌に対する ISR や有茎薄筋移植により永久 人工肛門の回避の可能性が高まっている。一方、患者の 意思決定の方法として效用值や Analytic hierarchy process (AHP) が試みられている。【目的】永久人工肛 門造設の可能性のある直腸癌手術において、効用値と AHP を用いて術式の決定過程を㭘討した。【対象と方 法】医学生70人と直腸癌患者 16 人を対象とし、奻用值の 測定と AHP を用いて直腸癌で dynamic graciloplasty (DG 群) と腹会陰式直腸切断術 (AP 群) の選択の意思 决定を行った。効用値の測定項目は腹部の永久人工肵門 と排便障害（軽度および重度の便失禁など）とした。洁 果】医学生では「腹部の人工肛門」の平均効用値は 0.36 であった。排便障害では、「便が常に漏れる状態」は0.14 でった。直腸癌患者では「腹部の人工肛門」の平均効 用値は0.49であり、排便障害では、「便が常に漏れる状丠」 が0.12であった。AHPによる意思決定の結果、医学生て は62人が DG 群、8人が AP 群であり、直晹癌患者ては 7 人が DG 群、9人が AP 群であった。【結論】以上の洁 果より、1）医学生でも直腸癌患者でも腹部の永久人工 肛門よりも術後の重度便失禁のほうが効用値は低加つ た。2)術式の選択は医学生と患者では異なった。3) 効用值と AHP は術式の選択の過程を明確にする可能性 が示唆された。 
SF-267

进伝的素因に基づいた大腸癌の術式選択 国立病院機講岩国医療センター外科

田中屋宏雨, 竹内仁司, 安井義政, 金川泰一朗,

中川仁志, 村田宏, 荒田尚, 谷口信将, 重安邦俊

近年、大腸癌の発絽には chromosomal instability 型と microsatellite instability 型の少なくとも2 2 の genetic pathway があることが明らかにされた。後者の 代表てある HNPCC は常染色体優性形式をとる最も頻

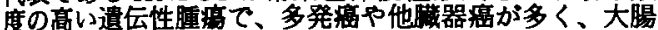
雷の衡式選択において考虑すべき因子のひとつてある。 自臨例における HNPCC の頻度は、確診例では14家系27 例て大腽癌手術例 $22.3 \%$ 、本邦 HNPCC 診断基萑 A-B にて拾い上げた疑診例を合めると6.3\%と高率であった。 HNPCCの手術では予防的臟器切除のコンセプトが重 要となるが、HNPCC の確診例か疑診例か、すなわち用 いた監床診断基準の種類や遗唇子検査施行の有無によ? て選抧も変わりうる。臨床診断基萑のみから HNPCCを

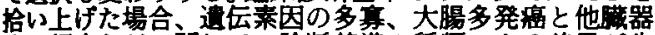

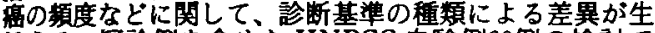

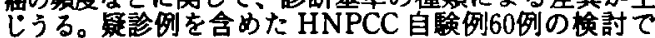

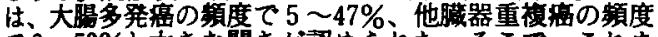
て9〜53\%と大きな開きが証められた。そこて、これま

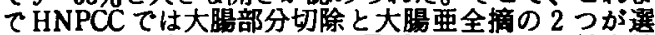
択膆として挙げられてきたが、最近われわれは、㹡大結 踷切除術を選択肢に取り入れた。発我リスクの高い結鹏 を埈大切除しつつ術後のQOL 低下を抑えることを期待 しており、HNPCC の高缽者や疑診例などを主な対象と 考えている。遗公的素因に基ついた大腸癌の術式選択に ついて、臨床診断や遗层子検査を含めて報告する。

SF-268 結腸虚術後補助化学㞠法選択に打ける CD-DST 法の有用性の検証

IHI 播磨病院外科 ${ }^{2}$, 兵庫県立谈路病院外科 ${ }^{21}$, 高砂市民 病院外科 ${ }^{3)}$, 神戸大学呼吸循眾器外科“

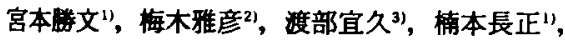
前田貝作

【はじめに】ベストな大腸㾇術後補助化学療法の選択に

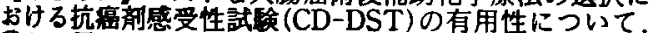
我々の行つている、臨床試駼の䋡中経過を報告する。【対 象および方法】2004年4月から2005年10月まてに手術を 募行した stage II および III 結腸癌15例に对して CDDST法による抗密郕感受性試菜を行った。CD-DST 法 の莧㓱接触条件は $5 \mathrm{FU} 1.0 \mu \mathrm{g} / \mathrm{ml} 7$ 日間, $5 \mathrm{FU} 10.0$ $\mu \mathrm{g} / \mathrm{ml} \mathrm{24}$ 時間、MMC $0.60 \mu \mathrm{g} / \mathrm{ml}$ 24時間とした。術後

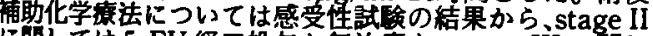

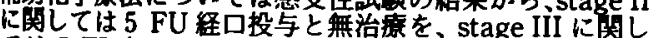
ては $5 \mathrm{FU} / \mathrm{LV} \pm 5$ FU 経口、MMC \pm 5 FU 程口、5 FU释口およひ無治瘻を用意した。なお、感受性試験不成 功例に対しては stage II では 5 FU 経口投与か無治癔 を、stage III では $5 \mathrm{FU} / \mathrm{LV}$ か無治寮を患者自身に選択 してもらった。【結果]感受性試会成功例は11例 $(73.3 \%)$ で、不成功例は 4 例 $(26.7 \%)$ でちた。成功例の各治境 法への制り付けは stage III て 5 FU/LV +5 FU 释口 が 6 例、5 FU/LV が 4 例となり、stage II で 5 FU 経口 が 1 例であった。有㝘事象の発生は 0 例て、全例におい

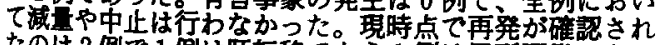
たのは2例で1例は位移でもう1例は局所再発であっ

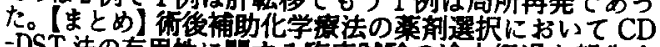
一ST 法の有用性に闺する臨床試涂の途中経過を報告す
SF-269 痔癌に対する診断と治療方針

恵庭第一病院外科 ${ }^{1)}$ ，札幌医科大学第 1 外科 ${ }^{2}$ ，札幌医科 大学整形外科 ${ }^{31}$, 札幌医科大学形成外科(4)，新札幌恵愛会 病院 ${ }^{5)}$

秦史壮 ${ }^{11}$, 矢嶋知己"1, 中島太"1, 鶴間哲弘2), 古㚼智久 ${ }^{21}$, 山口浩司 ${ }^{21}$, 挂巻正 ${ }^{2)}$, 木村康利 ${ }^{21}$, 平田公一2), 四ツ柳高敏 ${ }^{31}$, 名越智4), 江副英理 ${ }^{5)}$, 宍戸隆之 ${ }^{51}$, 柳内良之 ${ }^{5)}$ ，八十島孝博5)

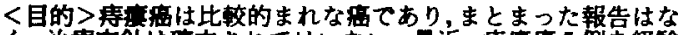

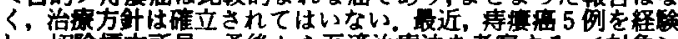
し. 切除原本所見, 予後加至通治港法を考察する。対象〉 2003年 4 月加ら2005年 4 月まて札幅医大第一外科て程験した

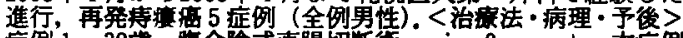

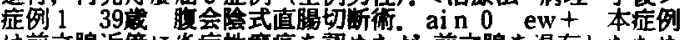
は前立腺近傍に炎症性痕を証めたか，前立腺を温存したため

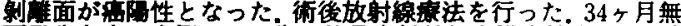

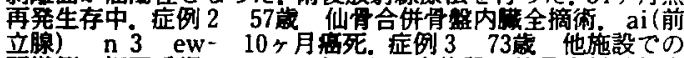

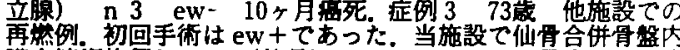

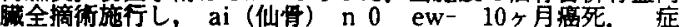

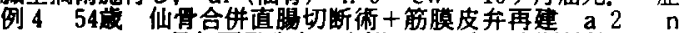

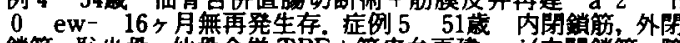

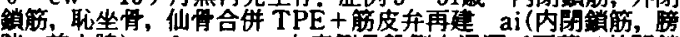

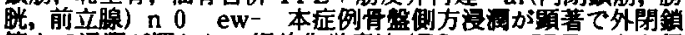

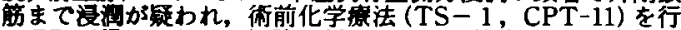
いPRが得られたため切除を行つた.9ラ月他病死。上記全例に

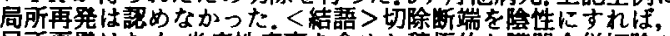

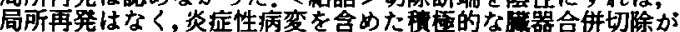

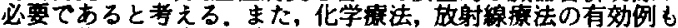
みられ集学的治奥が考虑されるべきであろう。

SF-270

当院における大腸蜜合併切除症例の検討 公立阿伎留病院外科

枈田昌彦, 阿部英雄, 矢鴂幸浩

大腸癌は肝、肺転移や多脸器の直接浸潤が切除可能であ れば長期の予後も期待できる。われわれは2006年 7 月よ り2008年 3 月まての21ヶ月間に経験した大腸密70例のう ち合併切除症例は11例で15.7\%てあり、ストーマ造設、 パイパス手術を除く60例のうちでは18.3\%と高率であっ た。合併切除を行なった症例は男 6 例、女 5 例で年战令は 57歳から88歳の平均68.1歳でちった。部位は盲腸 1 例、 上行結腸 2 例、横行結腸 1 例、S 状結腸 3 例、直腸 4 例て あった。病期は IIIa 4 例、IIIb 5 例、IV 2 例て、病理 組識は高分化腺癌 3 例、中分化腺蛼 6 例、低分化腺㾇 2 例であった。合併切除の腀器は腹壁筋 2 例、膀胱 2 例 ( 1 例は部分切除) 子宮 2 例 (1 例は䐋後暨を含む)、大網 1 例、盲腸 2 例、小腸 1 例、虫垂 1 例、胃 1 例、肝 1 例、

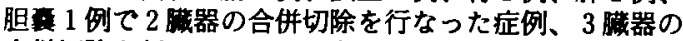
合併切除を行なったものが各 1 例て 9 例では 1 践器のみ の合併切除であった。予後は局所再発の1例が18ヶ月後 に、H 3 の肝転移症例が10ヶ月後に癌死したがそれ以外 の8 例は生存しており1例は転院して追跡できなかっ た。術後は77歳と88歳の 2 例を除き全症例で化学㞠法を 行なっている。このような症例には程極的な切除が行な われるべきと考えるが腸閉塞の有無や年龄、QOLなどを 充分に考虑して決めるべきてある。また術後補助化学瘄 法も検討すべきである。 
SF-271直腸早期癌に対する治療の選択

藤田保健徫生大学下部消化器外科

小出欣和, 前田耕太郎, 花井恒一, 佐藤美信, 升森宏次, 青山浩幸，船橋益夫，鎌野俊彰，野呂智仁，安形俊久， 本多克行, 青山敦子, 犬飼健太郎

直腸癌では，治療法別に，術後の排尿・性・排便機能障 害の程度が異なるため，選択された治療法により患者の 術後のQOLが左右される。そのため必要且つ充分な切 除範囲の治療法を選択すべきである。治療法の選択は, 主にリンパ䬣転移の可能性の有無によつて決定される が, 転移のリスクフフクターとして術前診断可能な因子 は、組織型と䇒深達度のみであるため, 術式決定に難涉 することが多い。我々の直腸早期㴼に対する治療方針は, 術前検查として直腸指診, 注腸造影検査, 内視鏡検査を 行い,これらのすべての検査で壁深達度が SM-slight と 診断された分化型腺瘦の場合や。もしくは検查所見間に, 壁深達度の不一致がみられた場合には，詳細な病理組繶 学的評価が可能な標本が得られる局所切除法を選択して いる。内視鏡で一括切除が確実に可能な病変では，内視 鏡摘除を行い，その他の病変では経肛門的摘除 (従来法、 MITAS) を行っている。すへで榙查所見てSM-mas sive と診断された場合は, 初回治療としてリンパ節郭清 を伴う腸切除を行っている。これまで直腸早期瘦に対し て MITAS を68例に施行した。68例中 m 癌は38例、sm 㿋は30例であった。68例すへてに一括切除が行われ詳細 な病理診断が可能な標本が得られた。選択した適切な症 例に対し局所切除を行うことにより，不必要な腸切除か 回避可能であるが，そのためには，詳細な病理組織診断 が可能な標本が得られる局所切除法を選択することが重 要である。

\section{SF-272}

大腸癌に対する小開腹手術の適応と成續

青森市民病院外科

橋爪正，昆祐理，佐藤利行，小野裕明，川嶋啓明，西隆， 柴崎至, 遠藤正章

【目的】2000年以降準進行癌に低侵睃，D 3 郭清可能な 7 $\mathrm{cm}$ 小開腹手術を常用したこの術式の妥当性と成綪を 提示する.【結果】2000〜2005年に90例を経験.通応は年 踰制限なく、深達度 SSまで(全周性を除く)、CTでリン 八゚節腫大(-)とした.柄つきガーゼで周囲满器を王排し， 開腹邻の移動をまめに行うと場の展開は良好て、腹腔内 で十分な視野か確保出来る。(操作に難造すると感じた

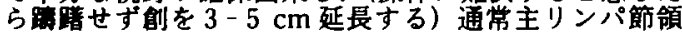
域直上で開腹し，中枢側の部清を先行する．儤管を体外に 挙上しないと良好な視野で no touch isolation $の$ 原則に かなう手技が可能となる.腸管口側，肛側の処理を早目に 施行すると周囲の立体的な局所解剖は確認しやすい.湖 腔内の熼察と助手側の視野がいくぶん不良なこと，皮下

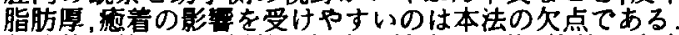
郭清後腸管 (膜)を㔀畋し標本を摘出した後。体外で吻合 することが多い，最近は機能的吻合を用いて手術時間の 短缩を計っている.重篇な合併症はないが術野感染 6.7 $\%$,腸閉塞 $3.3 \%$,早期精神障害 $2.2 \%$ な゙を認めた.現在 まて血行性再発を2 例(ss,n 0，2年後肺転移，ss，n 0 ， 3 年後所転移)に認めるのみである。【結論】小開腹法は 外科医になじみやすく低侵加つ短期 QOL は良好など 利点が多い. 医療安全と経済面から有利てあり，準進行癌 に対する標準術式として腹腔鏡下手術に匹敵する術式と 思われる。予後に及涩す影は不明なので十分な informed consent が必要でる。
SF-274 低侵意手術としてのミニラパの位罯づけ 名古屋第一赤十字病院外科

竹内英司, 小林陽一郎, 宮田完志, 後藤康友, 三宅秀夫, 長澤圭一, 石川玲, 安江敦, 高橋崇真, 三宅隆史, 雄谷慎吾

当院では、moving window 法を利用した小開腹大陽切 除術を導入し、現在までに120例に施行した。通応として

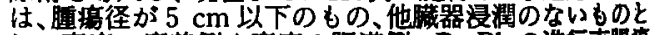
し、高度の淩着例や高度の肥満例、Ra Rb の進行直渴 は適広加ら除外している。手技は， $7 \mathrm{~cm}$ の皮成切閏她 え、創縁を Aplied Alexis $の$ M size (Applied Medical) にて保淁する。本法のコツは、通布を捕入して小鹉居 排し、通常の手術と同様の視野を展開すること、オム二 トラクトリトラクターシステム (mansson)により えず術野の中心に創を移動することが挙げられる。吻合 は手術時間の短縮と手術手技の安定化のため functional end to end anastomosis $も \zeta \zeta は$ double stapling techniqueによる器械吻合を用いた。術者としては、演暑 が約 1３３の症例を、6名のスタッフが約 $1 / 3$ 志名 $の 3$ 年目以上の外科レシテントが約 $1 / 3$ の手術を行 した。平均手術時間は130分、平均出血量 $110 \mathrm{~mL}$ て、㭘 症としてはイレウスを10例、SSIを6 6例、DVTを1知 に認めたが、䋖合不全はなかった。予後としては、手行 関連死はなく、術後合併症に起因する再手術もなかった。 2005年 5 月からは、術後 3 日目より食事を開始し、街後 8日目に退院可能となるクリテイカルパスを窟入し完 遂卒は93\%て、SSIはなく平均術後在院日数も10日とれ つた。本法は、通常の外科的を習得したものでるる 


\section{SF-275 術後創処置に減菌器材は不要である} 国立病院機構大阪医療センター外科

大村二昭, 柏崎正樹, 西田尚弘, 安井昌義, 石飛真人, 增田傎三, 池永雅一, 宮崎道彦, 平尾素宏, 高見康二, 藤谷和正, 三鳮秀行, 沢村敏郎, 中森正二, 过仲利政

【目的】当科では、2003年11月から手術創の被覆法をガ 一ゼドレッシング法からフィルムドレッシング法に変更 し、2005年 8 月には術後㓣処置に用いる器材の減菌を廃 止した。SSI サーベイランスの結果から術後創処置法変 更の妥当性を検討した。【対象および方法】2003年 8 月か ら2005年10月までに、清粱手術と開創ドレナージ術を除 く全身麻醉手術症例、1207例に対して SSIサーペイラン スを施行した。介入 (1)：2003年11月から 1 次觡合創の 消毒とガーゼ貼付を廃止し、フィルムドレッシング材で 被覆して48時間経過後に除去する方法に変更した。介入 (2)：2005年 8 月からドレーン刺入部の消毒も廃止し、 術後創処置には未减菌の器材を使用した。【結果】介入 (1)の前後各 3 ヶ月において、表層切開部位感染の発生 は $8 / 140(5.7 \%)$ から $10 / 123(8.1 \%)$ と有意な増加を認 めなかった $(\mathrm{p}=0.47)$ 。介入(2)の前後各 3 ケ月にお いてもSSI 発生率は15/144(10.4\%) から25/157(15. $9 \%)$ と有意な増加を認めなかった $(\mathrm{p}=0.18)$ 。【考察】手 街創を消毒してガーゼで被覆する従来の創処置法に対 し、当科で行っている消毒薬と隇菌器材を用いないドレ ッシング法は、患者と医療者双方の負担の軽減、コスト の削減、医療資源の節約に貢献している。この処置法の 妥当性は、2 度にわたる介入の前後で SSI 発生率の増加 を来さなかったことて担保されていると考えられた。

SF-276 当院での術後創処置における手術部位感
染の検討
相模原協同病院外科
保刈岳雄, 河野悟, 小池卓也, 笨美和, 吉田徹,
田中知博, 松下恒久, 相崎一雄, 川上新仁郎, 高野靖娪

【背景】当院ては、平成17年 4月より CDCガイドライン を準执して SSI 対策を開始し、SSI サーベイランスを行 つている。従来、術後創部処置に対してイソジンなど消 毒没による消毒を行っていた。消毒液は、創治慜遅延さ せることが現在言われている。平成17年12月より消毒液 による術後㓣処置を中止し、蒸留水による洗津とし、2 月からは水道水洗浄とした。【方法】平成16年10月から平 成17年 3 月まてのSSI 対策施行前の期間を A 期、SSI 対 策を始めた平成17年 4 月から11月までを B 期、水による 創処置を行った平成17年12月から平成18年 3月までをC 期として、消化器外科手術症例のSSI を統計学的模討す る。消毒菠創処監の中止による医療コストの削減費も検 討する。【結果】SSI 発生率は A 期 $14 \%$ 、B 期 $8 \%$ 、C 期 $11 \%$ A 期から B 期に有意差を認めたが B 期から C 期 に差を認めなかった。水創洗津を開始してからイソジン 菠、マスキン液の使用量が、月平均各々 18 ，3本、9.3本 減り、16189.5円/月のコスト削減となった。【考察】水 洗浄による原後創処置は、SSI 発生において消毒夜処置 と有意差を認めず、医療コスト削減も効果的であった。 SSI サーペイランスの結果から術後創処曾は、水道水て 十分であり医療経昘的にも有用であると考えた。

\section{SF-277}

術後離開創に対するハイドロファイバー

を用いた創処置方法

関西医科大学外科

山尾順, 里井壮平, 柳本泰明, 豊川秀吉, 松井陽一,

山本智久, 高井留一郎, 山道啓吾, 吉岡和彦, 上山泰男

術後離開創を含めた開放性の創偒処置は、洗浄やデブリ ードマンを行い異物や壊死組織を除去した上で、湿潤環 境を維持する必要がある。ガーゼは漫出液を吸収し、時 に創面を乾燥化し、交換時に感染の危険性や疼痛をもた らすばかりでなく、吸収力が比較的弱いため交換が頻繁 に必要であり医療コストの増大にもつながる。一方で、 ハイドロファイパーの利点として、優れた涪出液の吸収 力と水分保持力を有し、ゲル化した被㬓郕が創に遗残す ることが少なく、また、強度のあるゲル内に細菌を補足 するという特徽を有するため、創部の疼痛の緩和、ガー ぜ交換の頻度の隇少、肥厚性疫痕やケロイドの発生が少 ない、などがあげられる。われわれは術後離開創に対し、 生理食塩水による洗浄後、ハイドロファイバーを用いて 被覆した群とガーゼを用いて被覆した群で、創部が上皮 化した時点を治痹と判断しそれぞれの治虑期間を評価し た。その結果は、創 $1 \mathrm{~cm}$ あたりの治觙日数を比較した場 合、ハイドロファイバー群ではガーゼ群と比較して有意 に短縮していた。さらに、医療コストの比較でも有利て あった。また両群内より創培養陽性例を抽出し、創 $1 \mathrm{~cm}$ あたりの治疮日数を比較した場合、両群間で有意な変化 は認められなかった。今回、ハイドロファイバーを使用 した創処置方法を提示するともに、その成績についても 報告する。

SF-278 Dry dressing と Wet dressing --- 痛 み、患者ストレス、鎮痛剂投与期間、の锶点からの比較 屏風ヶ浦病院外科

矢野剖司，大島行彦

【はじめに】創傷管理において Wetdressing 法が広まり つつ有る。これ迄外来刢処真は軟素、ガーぜ交換といつ た Drydressing が主で処置毎にガーゼを制が痛みを 伴った。今回外来 3 ヶ月間の外䅞20例にWetdressing 法 を、15例にDrydressing 法を施行し患者側の痛み、スト レス、鎮痛斉投与期間の観点から比較、結果を報告する。 【方法】Wetdressing 法一消毒液は組䄉障害性を伴う為 微温湯で洗浄。湿潤考保つ為港出液の多い深い創には八 イドロポリマードレッシング材、出湾の少ない浅い創 には八イドロゲル材を使用。出血伴う症例はアルギン酸 塩を追加。極力縫合は行わなかった。壊死創は積極的に 石検水て洗浄。抗生剂処方は必要最小限ないし処方無し とした。Drydressing 法との比較は疼痛評価(フェイスス ケールと鎮演剂使用状涚)、アンケート結果で行った。(成 綪】Wetdressing 法は受筫直後の洗浄時に痛みを認める 他は処置中の痛みはスケール上ほほ 0 点、鎮痛成使用か 2 日以上は 3 例のみ。2 日目より創のジ+ワー洗浄が可 能、ガーゼ交换目的の通院を無くし自宅包交を主体とし た。Drydressing 法は毎回がーゼを剔がす度に患者側が ストレスを感じスケール上平均 3.6 点、鎮痛威は 2 日目以 降も必要とした。【結論】Wetdressing 法竞入て処置時の 疼痛軽減化を実現、他に保讙シャワーを廃し入浴時の手 間を簡易化、自宅包交を主体とし、時間に拘束されがち な会社員などのニースに応えられたなどの利点を認め t。 